\title{
Broiler Performance Given Carrot Waste Juice Meal As A Feed Supplement
}

\author{
R Noviadi $^{1^{*}}$ and GG Maradon ${ }^{1}$ \\ ${ }^{1}$ Animal Production Technology Study Program, Department of Animal Husbandry, \\ Politeknik Negeri Lampung, \\ *Corresponding author: riko_noviadi@polinela.ac.id
}

\begin{abstract}
Carrot waste contains various vitamins and carotenoid beta-carotene as provitamin A which is useful for improving broiler performance. The research objective was to determine the performance of broiler feeds given carrot waste juice meal as a feed supplement. The research was conducted in poultry cages at the Department of Animal Husbandry, Lampung State Polytechnic, from April to July 2020. The study was conducted in a completely randomized design with 4 treatments and 6 replications, each with 4 broilers. The treatments applied were $\mathrm{R} 0=0 \%$ carrot waste juice meal, $\mathrm{R} 1=1 \%$ carrot waste juice meal, $\mathrm{R} 2=2 \%$ carrot waste juice meal, and R3 $=3 \%$ carrot waste juice meal. The data from the research was carried out by analysis of variance if there was an influence on the variables then it was followed by Duncan's multiple distance test. The results showed that the use of carrot waste juice meal as a feed supplement with a level of $2 \%$ in broiler feeds produced the best performance.
\end{abstract}

\section{Introduction}

Broiler productivity optimization is achieved through the provision of nutrients following their needs. The nutrients in the feed will be digested, absorbed, and transported throughout the broiler's tissues and used for basic living, production, and reproduction. Broilers need nutrition quantitatively and qualitatively to support their production performance. The available nutrients will be utilized in the body of the broiler into a network of tendons through a series of complex processes and interacting with one another.

Nutritional interactions synergize with each other affecting biochemical processes in the broiler body. Several secondary chemical compounds found in natural ingredients such as carotenoids found in carrots can improve protein digestibility in broilers in tropical environments (Sejati et al., 2017). This mechanism works by providing coenzyme precursors to help the protein digestive enzymes work better. Thus, more and more protein is digested and utilized for the growth and development of the broiler's body. Carrot plants have several important nutrients, including $\beta$-carotene, Vitamin C $6 \mathrm{mg}$, vitamin E $0.66 \mathrm{mg}$, and minerals Ca 33--55 mg, and P 35--43 mg (Olalube et al., 2015). The content of beta-carotene in carrots is a precursor to forming vitamin A which functions as an antioxidant to ward off free radicals. Vitamin A also has many other benefits including being useful in the process of epithelialization of digestive cells, differentiation of epithelial cells, reproduction, and proliferation of intestinal mucosal cells (Muzaki et al., 2017). It is estimated that every $6 \mu \mathrm{g}$ of beta-carotene has a biological activity of $1 \mu \mathrm{g}$ of retinol. Beta carotene is important in nutritional needs as provitamin A. Betakaroten in the body of broilers will be converted into vitamin A in the intestinal mucosa and liver 
(Coultate, 1996) to become retinaldehyde by the enzyme carotene dioxygenase. Then, by using the enzyme retinol dehydrogenase, retinaldehyde is converted into retinol which is the main form of vitamin A. Vitamin A functions as a growth assistant, maintenance of eye health, healthy skin, and mucous membranes for protection against infection and helps normal development of bones and teeth (Tamzil in Ariqoh et al., 2019). In addition to the high provitamin A content, carrots also contain vitamin $\mathrm{C}$ and $\mathrm{B}$ vitamins and contain minerals, especially calcium and phosphorus.

Utilization of waste carrot juice meal as a feed supplement for broiler feeds is more economical through carrot tuber waste, which is a carrot that is not suitable for human consumption, characterized by blisters, holes, cracks, wounds, or wet spots. Most carrot tubers with poor quality are simply thrown away, if not used they will quickly rot, causing environmental pollution (Rafiqoh, 2019). The use of carrot waste in the form of dried juice meal in broiler feeds has higher effectiveness because it is easier to digest and absorb and in the same amount has more nutrients. Beta-carotene from carrot waste juice is a provitamin A which can increase the formation of vitamin A which is expected to increase the performance of broilers. The research objective was to determine the performance of broilers feeds given carrot waste juice meal as a feed supplement.

\section{Material and Method}

The tools used in the study are cage bulkheads, yellow tube, pan feeder, manual drinker, brooder, electric lamps, analytical scales, glass flasks, knives, label paper, glass bottles, trays, blenders, juicers, and electric ovens.

A total of 96-day old chick broilers strains of arbor acres were used in the study. The feed ingredients consist of a mixture of yellow corn, rice bran, broiler concentrate, and carrot waste juice meal. Hitchner strain ND vaccine was used on broilers at 4 days old, while Lasota strain was used at 28 days. Disinfectants are used for cage sanitation.

\subsection{Treatment and Nutritional Content}

The study was conducted in a completely randomized design (CRD), consisting of 4 treatments and 6 replications, each of which contained 4 broilers. The treatments applied were various levels of giving carrot waste juice meal in the feed:

$\mathrm{R} 0=0 \%$ carrot waste juice meal

$\mathrm{R} 1=1 \%$ carrot waste juice meal

$\mathrm{R} 2=2 \%$ carrot waste juice meal

$\mathrm{R} 3=3 \%$ carrot waste juice meal

The data obtained was analyzed of variance and if there was a difference between treatments then it was continued with Duncan's multiple range test (Steel and Torie, 1996). The treatment feeds consisted of yellow corn, rice bran, and broiler concentrate. The composition of each treatment feed and nutritional content are presented in Tables 1 and 2.

Table 1. Composition of treatment feeds

\begin{tabular}{lllll}
\hline Feed Ingredients & R0 & R1 & R2 & R3 \\
\hline Yellow corn (\%) & 54 & 54 & 54 & 54 \\
Rice bran (\%) & 7 & 7 & 7 & 7 \\
Broiler concentrate (\%) & 39 & 38 & 37 & 36 \\
Dried carrot waste juice (\%) & 0 & 1 & 2 & 3 \\
\hline Total & 100 & 100 & 100 & 100
\end{tabular}


Table 2. The nutritional content of treatment feeds

\begin{tabular}{lllll}
\hline Nutrient & R0 & R1 & R2 & R3 \\
\hline Crude protein (\%) & 22.26 & 21.96 & 21.64 & 21.33 \\
Crude fat (\%) & 3,87 & 3.83 & 3.79 & 3.75 \\
Crude fibre (\%) & 4.25 & 4.37 & 4.53 & 4.66 \\
Metabolic energy (kkal/kg) & $3,012.00$ & $3,010.37$ & $3,008.74$ & $3,007.11$ \\
Calsium (\%) & 1.15 & 1.12 & 1.09 & 1.07 \\
Phosphorus (\%) & 0.75 & 0.74 & 0.73 & 0.71 \\
Betacaroten (\%) & 0.253 & 0.256 & 0.259 & 0.262 \\
\hline
\end{tabular}

The cage sanitation and brooding installation were carried out for one week. The broiler is maintained for 5 weeks in the poultry cages of the Animal Husbandry Department, Lampung State Polytechnic. Feed and drinking water were given ad libitum. The brooding program was carried out for 14 days, followed by maintenance of the starter and finisher periods. Newcastle Disease Hitchner vaccination was given at 4 days old broilers intra-ocularly, meanwhile ND Lasota at 14 days using drinking water. Every day the feed is given and the rest is weighed.

Processing of carrot waste juice meal:

(1) Washing carrot waste with clean water.

(2) Draining carrot waste.

(3) Cutting carrot waste measuring $1--2 \mathrm{~cm}$.

(4) Put the carrot waste pieces into the juicer machine.

(5) Juicer shelter.

(6) Mixing carrot waste juice with flour (w/v).

(7) Drying the mixture of carrot waste juice and flour in an oven at $70^{\circ} \mathrm{C}$ for 24 hours.

(8) Weighing the feed ingredients and carrot waste juice meal according to the treatment feed formulation.

(9) Stirring the feed until it is homogeneous and feed packaging.

\section{Results and Discussion}

\subsection{Consumption of feeds}

The results of the analysis of variance showed that the addition of carrot waste juice meal to the feed had no significant effect $(\mathrm{P}<0.05)$ on the consumption of 5 weeks old broilers as shown in Table 3 .

Table 3. Average broiler consumption aged 5 weeks

\begin{tabular}{lllll}
\hline Treatment & R0 & R1 & R2 & R3 \\
\hline Feed consumption $(\mathrm{g} /$ head $)$ & $2,951.83^{\mathrm{a}}$ & $2,954,67^{\mathrm{a}}$ & $2,952,33^{\mathrm{a}}$ & $2953,17^{\mathrm{a}}$ \\
\hline
\end{tabular}

Note: Different superscripts show significant differences $(\mathrm{P}>0.05)$

The average consumption obtained in this study is higher than the research results by Muzaki et al. (2017) who get the value of broiler consumption at 5 weeks old between 2,631.40--2,680.88 g / head, but it is lower than the study by Huda et al. (2019) 3,252.52 g/ head. The use of carrot waste juice meal as a feed supplement up to a level of $4 \%$ has the same effect on broiler feed consumption. Active substances contained in carrots such as beta-carotene do not affect the consumption of broiler feeds. The main function of beta-carotene is a source of provitamin A which will be converted into active vitamin A as much as 15--20\% in the broiler body (Sejati et al., 2017). Physiologically, the essence of vitamin A for broilers have a function to maintain epithelial tissue normallyBroiler consumption is influenced by various factors including environmental temperature, health, immunity, 
the form of feed, nutritional balance, body size, growth rate, and most importantly the level of energy in the feed (Herlina et al., 2013)

\subsection{Weight Gain}

The results of the analysis of variance showed that the addition of carrot waste juice meal to the feed had a significant effect $(\mathrm{P}<0.05)$ on the weight gain of 5 weeks old broilers. The results of Duncan's multiple distance test showed significant differences $(\mathrm{P}<0.05)$ between treatments on broiler body weight gain (Table 4).

Table 4. Average broiler body weight gain in 5 weeks old

\begin{tabular}{lllll}
\hline Treatment & R0 & R1 & R2 & R3 \\
\hline weight gain $(\mathrm{g} /$ head) & $1.549,17^{\mathrm{a}}$ & $1.573,33^{\mathrm{b}}$ & $1.672,17^{\mathrm{c}}$ & $1.653,30^{\mathrm{d}}$ \\
\hline
\end{tabular}

Note: Different superscripts show significant differences $(\mathrm{P}>0.05)$

The use of carrot waste juice meal in the feed causes a difference in body weight gain between treatments because carrot waste contains several nutrients such as antioxidants in the form of beta carotene related to broiler growth, Increased levels of use of waste carrot juice meal as feed supplements can streamline the feed so that it significantly increases body weight of broilers. This condition caused the provitamin in the form of beta carotene in carrots to contribute to increasing the content of vitamin $\mathrm{A}$ in the broiler's body. The higher the beta-carotene in the feed, the higher the provitamin A is converted into vitamin A. According to Sahin et al. (2009) that vitamin A in carrots functions for cell differentiation. Epithelial cell differentiation affects the immune function of poultry and can increase feed efficiency and increase body weight (Prasetyo et al., 2018).

Carrots also contain vitamins C, E, B, and minerals (Asgar and Musaddad, 2006). The vitamin B complex found in carrots includes B1 (thiamine), B2 (riboflavin), B3 (niacin), and B6 (pyridoxine). There are not as many B vitamins in carrots as beta carotene. Vitamin B has a role as a coenzyme in the process of digestion of protein, especially vitamins B5 and B6. Vitamin B6 or pyridoxine is a coenzyme in several enzymes in amino acid metabolism in the process of transamination and decarboxylation (Triana, 2006). Vitamin B also plays a role in carbohydrate metabolism and growth.

\subsection{Feed Conversion}

The results of the analysis of variance showed that the addition of carrot waste juice meal to the feed had a significant effect $(\mathrm{P}<0.05)$ on the conversion of broiler feed at 5 weeks old. To see the difference in effect between treatments, Duncan's multiple range test was performed, and the results are shown in Table 5.

Table 5. The Average value of broiler feed conversion aged 5 weeks

\begin{tabular}{lllll}
\hline Treatment & R0 & R1 & R2 & R3 \\
\hline Feed conversion & $1,91^{\mathrm{a}}$ & $1,88^{\mathrm{a}}$ & $1,76^{\mathrm{c}}$ & $1,79^{\mathrm{c}}$ \\
\hline
\end{tabular}

Note: Different superscripts show significant differences $(\mathrm{P}>0.05)$

Table 5 shows that the use of carrot waste juice meal in the feed has a different effect on the conversion feed of broiler because the average of feed conversion in each treatment has the same value but results in different weight gain. The feed conversion is the value obtained by calculating the amount of feed consumption in a certain period divided by the gain in body weight obtained. The betacarotene contained in dry carrot waste juice serves as a precursor for vitamin A (Olalube et al., 2015) which will be formed into vitamin A in the broiler body. Tamzil (2014) argues that vitamin A functions in the epithelial and digestive tissues. Vitamin A is also responsible for the proliferation of intestinal mucosal cells, resulting in improved absorption of nutrients in the intestine. The more nutrients that are digested and utilized in the body of the livestock to be used for the formation of body weight of livestock. 


\section{Conclusion}

The use of carrot waste juice meal as much as $2 \%$ in the ration resulted in the best broiler performance.

\section{Acknowledgments}

To Politeknik Negeri Lampung for financial support through DIPA 2020 funds the contract number 193.11/PL15.8/PT/2020.

\section{References}

[1] Asgar, A and Musaddad, D. 2006. Optimization of Method, Temperature, and Length of Blanching Before Drying Carrots. J. Hort, 16 (3) 245-252.

[2] Ariqoh, H., Prayoga, S., Hermanto, B. S. and Hermana, W. 2019. Supplementation of Gotu Kola Leaf Juice and Carrot Waste on Productivity of Male Quail (Cortunix cortunix japonica). Journal of Nutrition and Feed Technology 17 (2): 54-58.

[3] Coultate TP (1996). Food-the chemistry of its components-2nd edit. The Royal Society of Chemistry, Cambridge.

[4] Herlina, R.B, R. Novita, T. K. 2013. Effect of Type and Time of Feeding on Growth Performance and Production of Broiler Chickens. Journal of Chem Indonesian Journal of Animal Science Vol. 10 No July 2 - December 201553 (9): 1689-1699.

[5] Huda, S., L. D. Mahfudz and S. Kismiati Effect of Step down Protein and Addition Acidifier of Feed on Broiler Chickens Performance. Indonesian Journal of Animal Science. Volume 14 Number 4 October-December 2019 edition.

[6] Muzaki, M. D. R., Mahfudz, L. D. and Muryani, R. 2017. The Effect of Using Flour Waste Carrots (Daucus Carrota L) In Rations Against Broiler Chicken Performance (The Effect of Waste carrot Product (Daucus Carrota L) Powder in The Diet on Broiler Chickens Performance). Animal Science 17 (1): 14-20.

[7] Olalude CB, Oyedeji FO \& Adegboyega AM. 2015. Physicochemical analysis of Daucus carota (carrot) juice for possible industrial applications. Journal of Applied Chemistry. 8 (8): 110-113.

[8] Sejati, P., Mahfudz, L, D. and Yunianto, V, D. 2017. Effect of the Use of Carrot Bulbs (Daucus carrota. L) Agricultural Flour in Rations on Protein Digestibility in Broiler AyaM. Journal of Agricultural Sciences 51 (2): 22-32.

[9] Steel, R. G. D. \& J. H. Torrie. 1980. Principles and Procedures of Statistics. A. Biometrical Approach. International Student End Mc Graw Hill. Kogakusha Limited, Tokyo.Tamzil MH. 2014. Heat stress in poultry: metabolism, consequences, and efforts to overcome it. Wartazoa. 24 (2): 37-66. 